\title{
Temporal characterisation of soil-plant natural recovery related to fire severity in burned Pinus halepensis Mill. forests
}

\author{
D. Moya ${ }^{\text {a,* }, ~ S . ~ G o n z a ́ l e z-D e ~ V e g a ~ a ~, ~ F . ~ G a r c i ́ a-O r e n e s ~}{ }^{\text {b }}$, A. Morugán-Coronado ${ }^{\text {b }}$, V. Arcenegui ${ }^{\text {b }}$, J. Mataix-Solera ${ }^{\text {b }}$, \\ M.E. Lucas-Borja ${ }^{\mathrm{a}}$, J. De las Heras ${ }^{\text {a }}$ \\ a Escuela Técnica Superior Ingenieros Agrónomos y Montes, Universidad de Castilla-La Mancha, Campus Universitario, 02071 Albacete, Spain

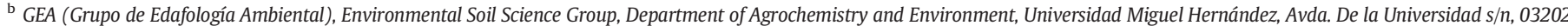 \\ Elche, Spain
}

\section{H I G H L I G H T S}

- The plant-soil interphase is related to fire severity and post-fire time.

- Fire severity affects ecosystem recovery in the short term.

- Plant recovery promotes soil biochemical recovery in the mid term.

- Soil properties recover in the long term after fire (21 years).

- The plant-soil window for natural recovery in semiarid areas is $15-21$ years.

\section{G R A P H I C A L A B S T R A C T}

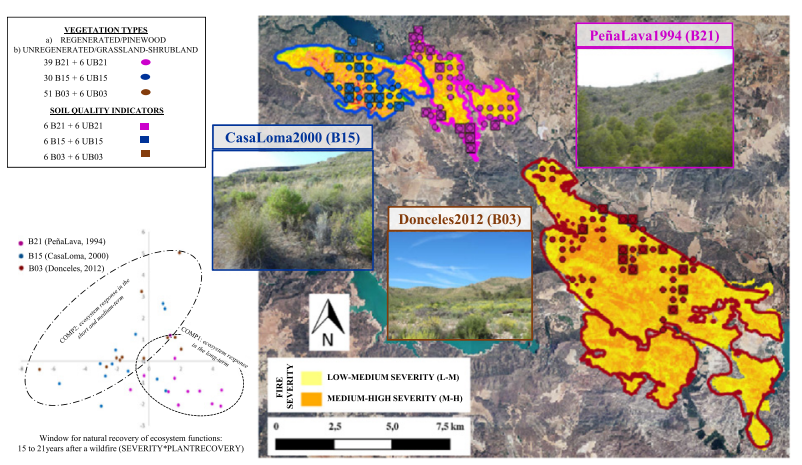

\section{A B S T R A C T}

Despite Mediterranean ecosystems' high resilience to fire, both climate and land use change, and alterations in fire regimes increase their vulnerability to fire by affecting the long-term natural recovery of ecosystem services. The objective of this work is to study the effects of fire severity on biochemical soil indicators, such as chemical composition or enzymatic activity, related to time after fire and natural vegetation recovery (soil-plant interphase). Soil samples from three wildfires occurring 3,15 and 21 years ago were taken in the south-eastern Iberian Peninsula (semiarid climate). Sampling included three fire severity levels in naturally regenerated (and changing to shrublands) Pinus halepensis Mill. forests.

In the short-term post-fire period, phosphorus concentration, electrical conductivity and urease activity were positively linked to fire severity, and also influenced $\beta$-glucosidade activity in a negative relationship. During the 15-21-year post-fire period, the effects related to medium-high fire severity were negligible and soil quality indicators were linked to natural regeneration success. The results showed that most soil properties recovered in the long term after fire (21 years).

These outcomes will help managers and stakeholders to implement management tools to stabilise soils and to restore burned ecosystems affected by medium-high fire severity. Such knowledge can be considered in adaptive

Abbreviations: SEVERITY, fire severity classification at three levels:; L-M, low-medium severity; M-H, medium-high severity; YEAR, Time after wildfire, years from fire to sampling in

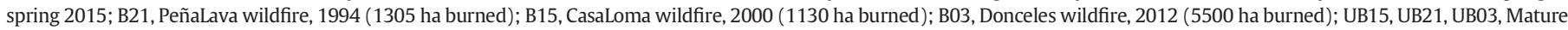

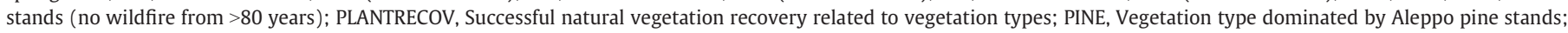

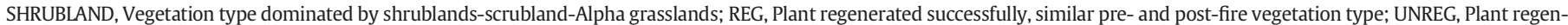
erated to a degraded successional post-fire stage.

* Corresponding author.

E-mail address: Daniel.Moya@uclm.es (D. Moya). 
forest management to reduce the negative effects of wildfires and desertification, and to improve the resilience of vulnerable ecosystems in a global change scenario.

\section{Introduction}

Fires are a major ecosystem process in Mediterranean biomes that play a key role in the distribution and composition of terrestrial ecosystems (Bond and Keeley, 2005). In the Mediterranean Region, fire acts as evolutionary pressure that shapes plant traits in ecosystems (Keeley et al., 2012). However, in the second half of the 20th century, fire regime changes were due mainly to climate change and rural collapse (Pausas and Keeley, 2014), which promoted increasing socio-economic costs (Dale et al., 2001). Indeed the number and size of wildfires increased in Spain and Portugal the whole year, and affected landscape change dynamics by reducing woodland surface, mainly in areas burned by large fires ( $>500$ ha) (San-Miguel-Ayanz et al., 2012). Fire plays an important role in the management of Mediterranean ecosystems, especially in arid and semiarid regions where biological soil stability in undermanaged stands is more vulnerable (Hedo et al., 2015). Fire recurrence also plays a key role in the vulnerability and resistance of the plant-soil interphase (Guénon et al., 2013), and should be considered in adaptive forest management (e.g. climate change, fire regime) (Doblas-Miranda et al., 2017). In Mediterranean ecosystems, fire recurrence higher than four in $<50$ years is a threshold to reduce woody cover, and endangers soil quality by affecting soil carbon cycling and microbial activity (Tessler et al., 2016; Zavala et al., 2014).

Mediterranean soils are sensitive to wildfires, but their impact depends on fire severity, recurrence and time after the fire (Bodí et al., 2013; Mataix-Solera et al., 2009; Bárcenas-Moreno et al., 2016; Vega et al., 2013b). Fire severity is defined as the loss of or a change in aboveground and belowground organic matter (Keeley, 2009; Vega et al., 2013a). It is the most critical factor that directly and indirectly affects vegetation (Vallejo et al., 2012) and soil response (Maia et al., 2012; Bárcenas-Moreno et al., 2016), especially in semiarid areas of the Mediterranean Basin (Hedo et al., 2015).

Soil-plant interphase feedback is a research priority to improve ecosystems management and to enhance their resilience. This includes standardised protocols and long-term monitoring to integrate results into models to predict soil changes after wildfires (Doblas-Miranda et al., 2015). The most widely used tools to identify the impact of disturbances and management practices are ecophysiological indices, such as the microbial quotient, the metabolic quotient or enzymatic activities related to soil microbiology (Bárcenas-Moreno et al., 2011; Hedo et al., 2015; Mataix-Solera et al., 2009; Zavala et al., 2014). Soil enzyme activities are a direct expression of the soil microbial community that link resource availability, structure and function to ecosystem processes (Caldwell, 2005). Fire affects soil properties directly, such as pH, and other processes indirectly, such as variations in the fungi/bacteria ratio (Bárcenas-Moreno et al., 2011; Mataix-Solera et al., 2009), or the enhancement of microbial activity related to high carbon availability and low nitrogen loss rates in dry soils (Choromanska and Deluca, 2002). With negative impacts, the recovery of the soil-plant interphase should be supported by implementing active tools to stabilise and restore disturbed ecosystems to enhance their resilience (Certini, 2005; DoblasMiranda et al., 2015).

Our study was carried out in Aleppo pine forests (Pinus halepensis Mill.), which are the most widely distributed forests throughout the low altitude areas of the Mediterranean Basin (Quezel, 2000). Aleppo pine is a pioneering obligate seeder with a dual-life strategy and precocious reproduction that bears both serotinous and nonserotinous cones, is adapted to summer droughts, and is exaptated to wildfires (Keeley et al., 2012). Several studies have focused on its post-fire vegetation in semiarid stands (Alfaro-Sánchez et al., 2014; Moya et al., 2015). Synchronic studies have corroborated the fact that resilient plant communities, such as Aleppo pine forests in the Mediterranean Basin (Capitanio and Carcaillet, 2008; González-De Vega et al., 2016), rapidly recover following the initial floristic composition model of Egler (1954). However, these studies exclude soil recovery. In the Aleppo pine stands that occur in SE Spain, changes in fire regimes and increasing fire severity have reduced the time window for the "immaturity risk" and have induced land use changes that range from pine forests to shrublands (González-De Vega et al., 2016). In these ecosystems, the structure of plant functional groups and fire severity not only influence soil enzymatic activity through alterations in nutrient cycling dynamics, but reduce resilience in these drought- and fire-prone areas (López-Poma and Bautista, 2014; Hinojosa et al., 2016). However, both fire resistance and the working scale influence fire damage to soil (Diaz-Delgado et al., 2003; López-Poma and Bautista, 2014). The main objective was to evaluate the effect of plant recovery, burn severity and time after fire on soil properties in three burnt areas undisturbed for different periods lasting 3,15 and 21 years. We characterised fire damage on soil by implementing a synchronic approach by recording different quality soil indicators in three large wildfires and relating them to fire severity, natural plant recovery and time after fire. The initial hypothesis was that the unburned areas showed similar soil and vegetation conditions before fires. In this way, the variability and relationships found for quality soil indicators were related to the short-, mid- and long-term post-fire periods, and also to fire severity and the plant community recovery.

\section{Materials and methods}

\subsection{Site description and fire severity mapping}

The experimental design was applied to three burned areas in the summers of 1994, 2000 and 2012 in SE Spain, separated by $<15 \mathrm{~km}$ and from the town of Hellin (in the province of Albacete). These areas presented similarities in vegetation, soil, and climate terms, and had remained unburned for $>80$ years according to the fire perimeters provided by the Forest Services of the Regional Castilla-La Mancha Government.

The study area has a semiarid Mediterranean climate and is located on the upper meso-Mediterranean bioclimatic belt. The average precipitation and annual temperature values are $278.5 \mathrm{~mm}$ and $15.85^{\circ} \mathrm{C}$, respectively (based on the 25-year data period from 1990 to 2014 provided by the Spanish Meteorological Agency). The dry period usually goes from June to September, during which relative humidity is below $50 \%$. The studied soils belong to the order Aridisol, suborder Calcid (Soil Survey Staff, 2014) and have a sandy-clay-loam soil texture ( $57.32 \pm 2.95 \%$ sand, $30.52 \pm 5.66 \%$ clay and $12.16 \pm 5.96 \%$ silt $)$. The predominant landform is composed of dolomitic limestones that shape strong rocky slopes, whose altitudes range from 500 to $700 \mathrm{~m}$ a. s.l. The landscape comprises similar topographic characteristics, plains and hills on which fields and natural vegetation settle. Following Rivas-Martínez (1982), the vegetation series belong to Rhamno lycioidis-Querceto cocciferae sigmetum. Before fires, the following grew in the area: Pinus halepensis Mill. (Aleppo pine), Macrochloa tenacissima (L) Kunth (Alpha grass), Quercus coccifera L. (Kermes oak) and Pistacia lentiscus L. (Mastic tree). In the 19th century, the landscape underwent land-cover and land-use changes, which enhanced the economic benefit of Alpha grass, abandoned in the late 20th century. 
We used images from the Landsat 7 Enhanced Thematic Mapper Plus (ETM+) data to calculate the delta-normalised burn ratio (dNBR) and to devise a fire severity map (Miller and Thode, 2007) of the most recent wildfire (Donceles, summer 2012). The fire severity map was improved with vegetation (amount of green, charred and scorched vegetation in trees, shrubs and herbaceous stratum) and soil severity (ash colour, biological soil crusts, soil horizon affection and bare soil), recorded in fields after fire (Gómez-Sánchez et al., 2017). The fire severity classifications were extrapolated to the other wildfires to establish two fire severity categories, low-medium severity (L-M) and medium-high severity $(\mathrm{M}-\mathrm{H})$, including unburned areas $(\mathrm{UB})$ as the control and mature plots.

The approach to monitor the ecosystem's response to fire was based on the synchronic plant-soil sampling done in spring 2015. Following Alloza et al. (2014), a systematic grid of $500 \times 500 \mathrm{~m}$ overlapped the fire perimeters to define the coordinates of the sampling plots, located on the grid nodes. The study areas were named using key names, built as dual descriptors: firstly, a letter to characterise if the plot was located on a burned area (B) or an unburned one close to the wildfire perimeter (UB); secondly, a number to define the time (years) that had elapsed from fire passage to 2015 (Fig. 1):

- B21: PeñaLava fire ( $X=602465, Y=4260123$, ETRS89 UTM 30N) ignited on 19 July 1994 and burned 1305 ha.

- B15: CasaLoma fire ( $\mathrm{X}=597303, \mathrm{Y}=4260532$, ETRS89 UTM 30N) ignited on 3 August 2000 and burned circa 1130 ha.

- B03: Donceles fire ( $\mathrm{X}=608309, \mathrm{Y}=4254211$, ETRS89 UTM 30N) ignited on 1 July 2012 and burned $>5500$ ha.

- UB15, UB21, UB03: unburned areas close to each wildfire perimeter.

\subsection{Vegetation sampling}

Pre-fire vegetation was characterised by both field sampling and digital cartography. The Geographic Information National Centre (the Spanish National Plan for Aerial Orthophotography) provided aerial geometrically rectified images (ECW format, geodetic reference system ETRS89) recorded the spring before each wildfire (June 1994, June 2000 and May 2012) and in spring 2015. The pre- and post-fire vegetation located on the grid nodes that overlapped the aerial photographs was characterised according to the main vegetation types defined by González-De Vega et al. (2016); i.e. Aleppo pine stands (PINE) subdivided into three levels according to tree density (closed stands (canopy cover fraction $>60 \%$ ), dense stands (30\% < canopy cover fraction $<60 \%$ ) and open stands (canopy cover fraction $<30 \%$ )) and shrublands-scrubland-Alpha grasslands (SHRUBLAND), according to the predominant plant types (suffrutescent plants, scrub cover fraction $>20 \%$ and Alpha grass cover $>60 \%$, respectively). Subsequently, the recorded vegetation types were validated with the results obtained by field sampling, done almost simultaneously to the date when the aerial images were taken.

The vegetation sampling plots were circular (5-metre radius; $78.5 \mathrm{~m}^{2}$ ) and set with a Magellan GPS receiver (Garmin International, Inc., Olathe, KS, USA) in June 2015. In all, 120 plots were established and sampled in late spring 2015: 39 plots in B21, 30 plots in B15 and 51 plots in B03 (plus six unburned plots per wildfire). The studied plots were those with a similar orientation, slope, percentage of bare soil and vegetation (both structure and composition) to prevent variability from those factors.

We characterised plant recovery as regenerated (REG) or unregenerated plots (UNREG) by comparing the pre- and post-fire vegetation types. The REG plots in which any vegetation occurring after fire was characterised as a vegetation type integrated into a class of Aleppo pine stand (canopy cover fraction above 50\%). UNREG were those that occurred in a degraded successional stage after fire; i.e. forest to shrublands, shrublands to grasslands, or bare soil percentages increased to above $50 \%$. To prevent unbalanced plot selection related to the occurring vegetation type (could affect soil microbiology), three recovered and three unrecovered plots were sampled from both the dominant vegetation types (forests and shrublands) in the burned and unburned plots.

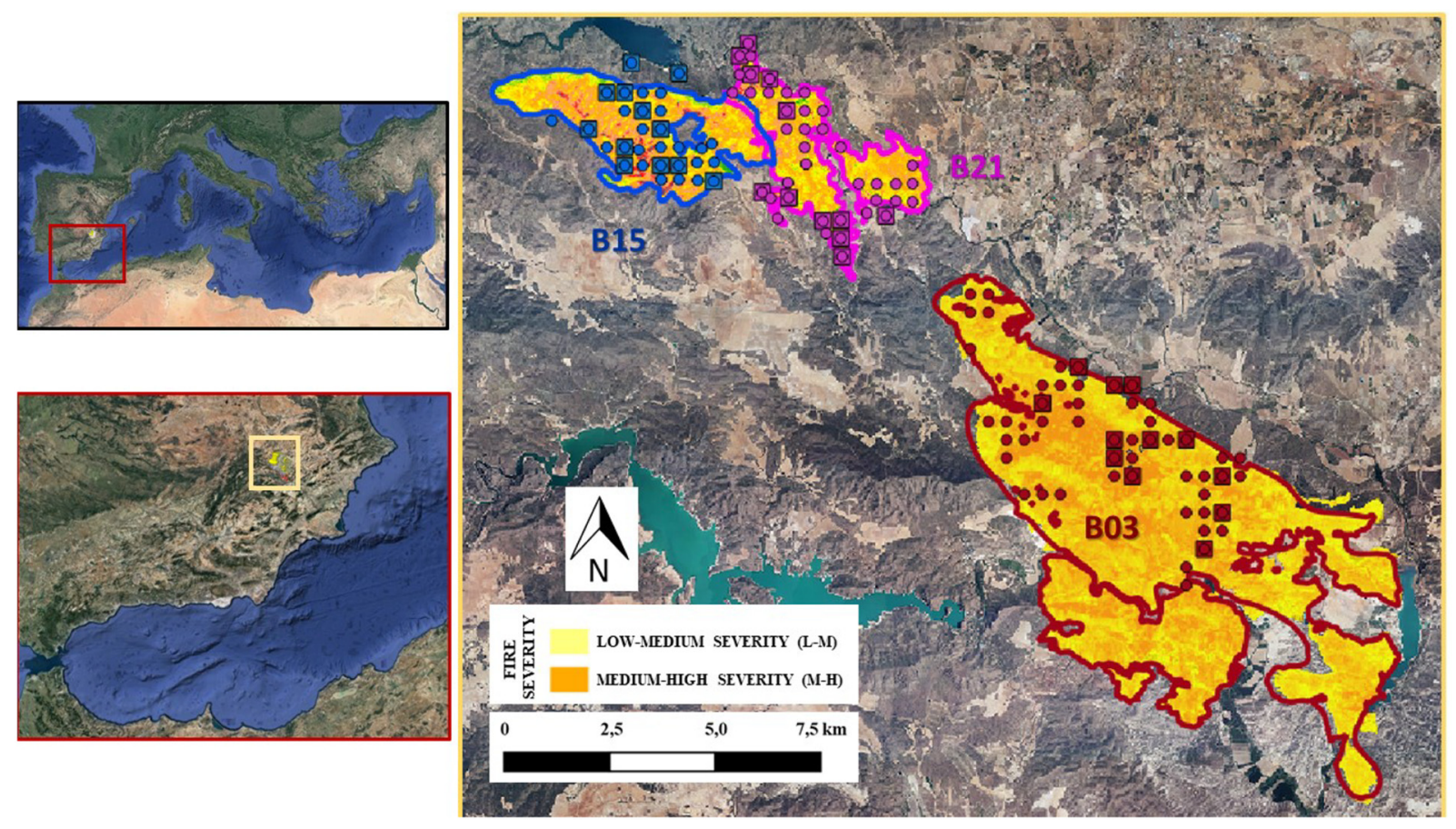

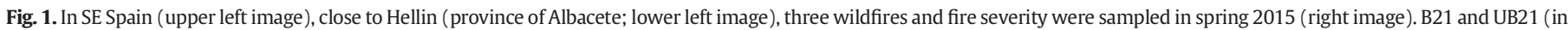

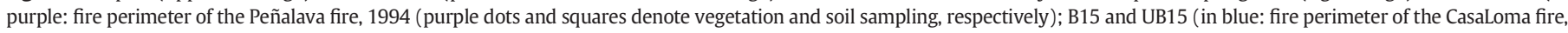

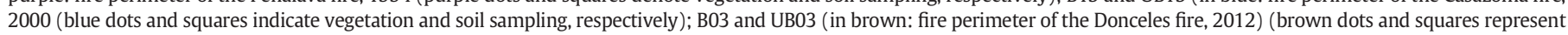
vegetation and soil sampling, respectively). (For interpretation of the references to colour in this figure legend, the reader is referred to the web version of this article.) 


\subsection{Soil sampling and analysis}

The experimental design indicated a sampling size of at least 36 soil samples to include all the described factors: 2 replicates $* 3$ sites (YEAR) $* 3$ fire severity (SEVERITY) $* 2$ types of natural vegetation recovery (PLANTRECOV). In June 2015, and simultaneously to vegetation sampling, 36 soil samples were randomly collected in areas with gentle slopes $(<5 \%)$ from the upper 5 -cm layer prior to litter removal from the two main plant recovery types within each site. Following Hedo et al. (2015), each one was composed of six mixed subsamples obtained from a $2 \times 2 \mathrm{~m}$ subplot located at least $200 \mathrm{~m}$ apart to avoid repetitions and pseudo-replication. After removing plant remains and debris, samples were passed through a $2-\mathrm{mm}$ sieve and were kept at $4{ }^{\circ} \mathrm{C}$ to avoid any influence on the parameters analysed in the laboratory (BárcenasMoreno et al., 2016).

The physico-chemical characterisation approach was based on a soil analysis to record texture, $\mathrm{pH}$, total nitrogen ( $\mathrm{N}, \mathrm{ppm}$ ) (Bremmer and Mulvaney, 1982), available phosphorus (P, ppm) (Olsen and Sommers, 1982), sodium (Na), calcium (Ca), potassium (K) and magnesium $(\mathrm{Mg})$ (meq $100 \mathrm{~g}^{-1}$ ), soil organic carbon (Corg, $\mathrm{g} \mathrm{kg}^{-1}$ ), cation exchange capacity (CEC, meq $100 \mathrm{~g}^{-1}$ ) and electrical conductivity (EC, $\mathrm{dS} \mathrm{m}^{-1}$ ). Corg was determined by the potassium dichromate oxidation method (Nelson and Sommers, 1982). The texture analysis was performed by the international Robinson pipette method to obtain the percentage distribution of individual soil particles according to size (Gee and Or, 2002), calculated with the Soil Texture Calculator (Soil Survey Staff, 2014). Soil pH and EC were measured in deionised water (1:2.5 and $1: 5 \mathrm{w}: \mathrm{w}$, respectively) at $20^{\circ} \mathrm{C}$. CEC was measured following Roig et al. (1980).

The biological approach indicators of soil quality (MorugánCoronado et al., 2015), such as basal soil respiration (BSR, $\mathrm{mg} \mathrm{CO}_{2}-$ $\mathrm{C} \mathrm{kg}^{-1}$ soil per $\mathrm{h}$ ), microbial biomass carbon (Cmic, $\mathrm{mg} \mathrm{kg}^{-1}$ soil), the carbon mineralisation coefficient (Cmineral, $\mathrm{mg} \mathrm{C}_{-} \mathrm{CO}_{2} \mathrm{~g}^{-1} \mathrm{Corg} \mathrm{h}{ }^{-1}$ ) (1), the metabolic quotient $\left(\mathrm{qCO}_{2}, \mathrm{mg} \mathrm{CO}-\mathrm{C} \mathrm{kg}^{-1}\right.$ soil per $\left.\mathrm{h}\right)(2)$ and the microbial quotient (Cmic:Corg, \%) (3), were analysed in soil samples. BSR was measured by a multiple sensor respirometer (MicroOxymax, Columbus, OH, USA). Following Bárcenas-Moreno et al. (2016), Cmic was determined by fumigation-extraction techniques (Vance et al., 1987).

Cmineral $=\frac{\text { basal soil respiration }(\text { BSR })}{\text { soil organic carbon }(\text { Corg })}$

$\mathrm{qCO} 2=\frac{\text { basal soil respiration }(\mathrm{BSR})}{\text { microbial biomass carbon }(\mathrm{Cmic})}$

Cmic $:$ Corg $=\frac{\text { microbial biomass carbon }(\mathrm{Cmic})}{\text { soil organic carbon }(\text { Corg })}$

enzymatic activities were also included as biochemical indicators, as were the activities of four main enzymes: urease (UR, $\mu \mathrm{mol} \mathrm{NH}{ }_{4}^{+} \mathrm{g}^{-1-}$ $\mathrm{h}^{-1}$ ), dehydrogenase (DHA, $\mu \mathrm{g}$ INTF $\mathrm{g}^{-1}$ ), phosphatase (PHP, $\mu \mathrm{mol}$ PNP $\mathrm{g}^{-1} \mathrm{~h}^{-1}$ ) and $\beta$-glucosidase (GLU, $\mu \mathrm{mol} \mathrm{PNP} \mathrm{g}^{-1} \mathrm{~h}^{-1}$ ). UR was assayed by taking urea as the substrate (Tabatabai, 1994). DHA was determined according to García et al. (1997). PHP and GLU were established using $p$-nitrophenyl phosphate disodium (PNPP, $0.115 \mathrm{M}$ ) and $p$-nitrophenyl- $\beta$-D-glucopyranoside (PNG, $0.05 \mathrm{M}$ ) as substrates, respectively (Tabatabai, 1994).

\subsection{Statistical analysis}

We evaluated the effects of time after fire (YEAR), burn severity (SEVERITY) and plant recovery (PLANTRECOV), and their interactions on the soil variables. We performed Generalised Linear Models (GLMs), including stepwise regression method (backwards) to choose the predictive variables by taking a sequence of F-tests, $R^{2}$ and adjusted $R^{2}$, including the Durbin-Watson test, to check no auto-correlation. Depending on the found dependant variables, we used multivariate analyses of variance (MANOVA) and one-way analyses of variance (ANOVA). Squared correlation coefficients and empirical p-values (assumptions included spatially independent subplots) were obtained. If significant differences were observed, the post hoc test applied was Tukey's honestly significant difference (HSD method) with a critical p-value of 0.05 .

To satisfy the assumptions of the equality of variance and normal distribution, variables were square root-transformed whenever necessary. We ran a correlation analysis by performing a multivariate statistical method analyses following Pearson's method. A correlation matrix was obtained and included the significance and level of complexity in the interrelationship of variables. A principal component analysis (PCA, varimax rotation method) was performed that included all the variables and factors. The structure of the dependence and correlation between the physico-chemical soil properties and the quality soil indicators at two levels (time after fire and fire severity) were calculated. In the PCA, the missing values were estimated and a standardised correlation matrix covariance was created list-wise based on complete cases. The PCA reduced the variables used by employing linear combinations and accounted for most of the variability contained in the original data. Statgraphics Centurion XV, version 15.1.02 (StatPoint, Inc., 2005) and SPSS statistics for windows, version 22.0 (Armonk, NY, USA: IBM Corp, 2013), were used to run the statistical analyses.

\section{Results}

A MANOVA analysed the variables recorded in UB, and showed no significant differences in the UB soil sample characteristics. This finding corroborated that the soils of the study areas were similar before fires. The clay and sand percentages revealed no significant differences after fire, but the silt percentage was related directly to SEVERITY and YEAR, with the highest increase in M-H severity in the short term (B03).

\subsection{Effects of YEAR, PLANTRECOV and SEVERITY on soil characteristics}

\subsubsection{Physico-chemical variables}

The GLM results showed a direct influence of YEAR and YEAR* PLANTRECOV on the $\mathrm{pH}$ values (Table 1 ). The $\mathrm{pH}$ values obtained lower values in B03 and B15 than in B21 (Table 2a), and were significantly lower in the REG plots (7.98 \pm 0.06 and $8.00 \pm 0.05$ in B03 and $\mathrm{B} 15$, respectively) than in the UNREG ones $(8.23 \pm 0.060 .07$ and 8.12 \pm 0.09 in B03 and B15, respectively) or in B21 (8.30 \pm 0.07 and 8.37 \pm 0.05 in REG and UNREG, respectively).

The EC values were significantly affected by YEAR, PLANTRECOV $* \mathrm{SE}-$ VERITY and YEAR $*$ SEVERITY (Table 1 ). The highest values were found in B03 $\left(0.31 \pm 0.03 \mathrm{dS} \mathrm{m}^{-1}\right)$ (Table 2a) and were higher in the REG plots than in the UNREG ones (B21 gave the lowest EC value in UNREG: $0.23 \pm 0.01 \mu \mathrm{S} \mathrm{cm}^{-1}$ ) (Fig. 2a). The EC values were lower in the burned areas than in UB in both the mid and long terms, but no differences were found between M-H and UB in B03, although L-M SEV was higher than UB (Fig. 3).

Factor PLANTRECOV was linked to CEC (Table 1). The ANOVA showed higher values in the UB plots, and the CEC in the pine forest stands was significantly higher $\left(0.31 \pm 0.01 \mathrm{meq} 100 \mathrm{~g}^{-1}\right)$ than in the shrubland stands $\left(0.22 \pm 0.01\right.$ meq $\left.100 \mathrm{~g}^{-1}\right)$ (Table $\left.2 \mathrm{~b}\right)$.

SEVERITY and the YEAR * SEVERITY interaction directly influenced primary macronutrients $\mathrm{P}$ and $\mathrm{N}$, respectively (Table 1 ). The greater SEVERITY, the higher the p values, which ranged from $3.50 \pm$ $0.60 \mathrm{ppm}$ in UB to $5.67 \pm 0.38 \mathrm{ppm}$ in $\mathrm{M}-\mathrm{H}$ (Table $2 \mathrm{c}$ ). $\mathrm{N}$ content was higher in the REG plots, with a maximum in B15 (Fig. 2b). Regarding secondary macronutrients, Na was affected directly by YEAR and $\mathrm{Mg}$ by the PLANTRECOV $*$ SEVERITY interaction (Table 1 ). The Na values in the short and mid terms were similar, but higher than in B21 (Table 2a). The Mg values were higher in B03 than in B15 and B21, and were higher those in REG than in UNREG (Fig. 2c). 
Table 1

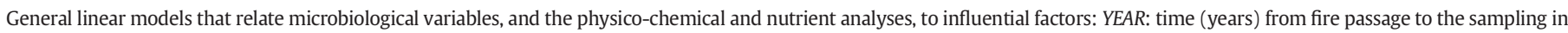

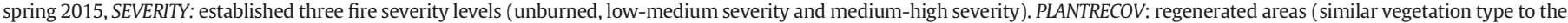
pre-fire conditions) or unregenerated (degraded vegetation types, mainly from a pine type to a shrubland type).

\begin{tabular}{|c|c|c|c|c|c|c|}
\hline \multirow[t]{2}{*}{ Variable } & \multirow[t]{2}{*}{ p-Value } & \multirow[t]{2}{*}{$\mathrm{R}^{2}$} & $\mathrm{R}^{2}$ & \multirow[t]{2}{*}{ Durbin-Watson } & \multirow[t]{2}{*}{ Factor interaction } & \multirow[t]{2}{*}{ p-Value } \\
\hline & & & (Adjusted) & & & \\
\hline \multicolumn{7}{|c|}{ Physicochemical variables } \\
\hline \multirow[t]{2}{*}{$\mathrm{pH}$} & $<0.01$ & 29.01 & 24.71 & 0.01 & Year & 0.02 \\
\hline & & & & & Plant recovery $*$ severity & 0.01 \\
\hline \multirow[t]{3}{*}{ EC } & $<0.01$ & 46.11 & 41.06 & 0.24 & Year & $<0.01$ \\
\hline & & & & & Plant recovery $*$ severity & $<\mathbf{0 . 0 1}$ \\
\hline & & & & & Year $*$ severity & 0.01 \\
\hline CEC & 0.04 & 11.52 & 8.92 & 0.00 & Plant recovery & 0.04 \\
\hline $\mathrm{N}$ & 0.02 & 15.90 & 13.42 & 0.02 & Plant recovery $*$ severity & 0.02 \\
\hline $\mathrm{P}$ & 0.03 & 19.46 & 14.58 & 0.70 & Severity & 0.01 \\
\hline $\mathrm{Na}$ & $<0.01$ & 24.89 & 22.68 & 0.54 & Year & $<0.01$ \\
\hline $\mathrm{Mg}$ & $<0.01$ & 33.08 & 29.03 & 0.21 & Plant recovery $*$ severity & 0.01 \\
\hline \multicolumn{7}{|c|}{ Microbiological variables } \\
\hline Corg & $<0.01$ & 22.00 & 19.71 & 0.01 & Plant recovery $*$ severity & 0.01 \\
\hline Cmic:Corg & 0.02 & 15.68 & 13.20 & 0.12 & Plant recovery & 0.02 \\
\hline UR & 0.01 & 16.64 & 14.18 & 0.11 & Severity & 0.01 \\
\hline \multirow[t]{2}{*}{ GLU } & $<0.01$ & 19.18 & 16.80 & $<0.01$ & Year & 0.02 \\
\hline & & & & & Year $*$ severity & 0.01 \\
\hline BSR & 0.03 & 12.80 & 10.24 & 0.67 & Year & 0.03 \\
\hline
\end{tabular}

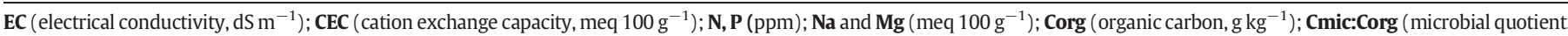

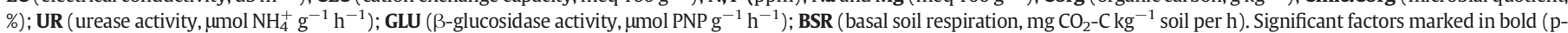
Value $<0205)$.

\subsubsection{Microbiology}

The GLM analysis highlighted a significant and direct influence of PLANTRECOV on the Cmic:Corg values, but Corg was related to the PLANTRECOV $*$ SEVERITY interaction (Table 1 ). The Cmic:Corg index was higher in the shrubland stands and UNREG plots $(2.40 \pm 0.33$ and $1.63 \pm 0.25 \%$, respectively) than in the pine forest stands and REG plots (Table 2b). The MANOVA showed higher Corg values in the REG plots, but they lowered according to time after fire, with maximum values in B03 and B15 (4.79 \pm 0.62 and $5.55 \pm 0.74 \mathrm{~g} \mathrm{~kg}^{-1}$, respectively) and the minimum value in the UNREG of B21 (2.14 \pm $0.33 \mathrm{~g} \mathrm{~kg}^{-1}$ ).

\section{Table 2}

One-way analysis of variance (ANOVA) of the significant factors obtained in Table 1: a) time after fire (YEAR (B21, B15, B03); b) plant recovery (PLANTRECOV (REG or UNREG (regenerated or degraded vegetation types); PINE or; SHRUB (in UB stands); c) fire severity (SEVERITY (UB, L-M, M-H). Featured values show the mean and standard error, while small letters indicate the significant differences between means of groups (Tukey's honestly significant difference (HSD) method).

\begin{tabular}{|c|c|c|c|c|}
\hline \multicolumn{5}{|l|}{ a. Year } \\
\hline & B21 & \multicolumn{2}{|l|}{ B15 } & B03 \\
\hline $\mathrm{pH}$ & $8.33 \pm 0.04^{a}$ & \multicolumn{2}{|c|}{$8.05 \pm 0.05^{b}$} & $8.11 \pm 0.06^{b}$ \\
\hline EC & $0.24 \pm 0.01^{\mathrm{a}}$ & \multicolumn{2}{|c|}{$0.24 \pm 0.01^{\mathrm{ab}}$} & $0.31 \pm 0.03^{b}$ \\
\hline $\mathrm{Na}$ & $1.16 \pm 0.06^{a}$ & \multicolumn{2}{|c|}{$1.14 \pm 0.03^{a}$} & $0.96 \pm 0.05^{b}$ \\
\hline GLU & $0.27 \pm 0.03^{a}$ & \multicolumn{2}{|c|}{$0.54 \pm 0.04^{b}$} & $0.48 \pm 0.02^{b}$ \\
\hline BSR & $0.92 \pm 0.14^{a}$ & \multicolumn{2}{|c|}{$1.63 \pm 0.24^{b}$} & $1.73 \pm 0.27^{b}$ \\
\hline \multicolumn{5}{|c|}{ b. Plantrecov } \\
\hline & Pine & Shrub & Reg & Unreg \\
\hline CEC & $0.31 \pm 0.01^{a}$ & $0.22 \pm 0.01^{b}$ & $0.27 \pm 0.02^{b}$ & $0.24 \pm 0.01^{b}$ \\
\hline Cmic:Corg & $1.12 \pm 0.26^{\mathrm{a}}$ & $2.40 \pm 0.33^{b}$ & $1.41 \pm 0.22^{\mathrm{a}}$ & $1.80 \pm 0.27^{\mathrm{a}}$ \\
\hline \multicolumn{5}{|c|}{ c. SEVERITY } \\
\hline & UB & \multicolumn{2}{|l|}{ L-M } & M-H \\
\hline $\mathrm{P}$ & $3.50 \pm 0.60^{a}$ & \multicolumn{2}{|c|}{$4.59 \pm 0.11^{b}$} & $5.67 \pm 0.38^{c}$ \\
\hline UR & $0.58 \pm 0.07^{\mathrm{a}}$ & \multicolumn{2}{|c|}{$0.85 \pm 0.06^{b}$} & $0.97 \pm 0.05^{c}$ \\
\hline
\end{tabular}

$\overline{\text { EC (electrical conductivity, dS m }}{ }^{-1}$ ); CEC (cation exchange capacity, meq $100 \mathrm{~g}^{-1}$ ); $\mathbf{P}$ (ppm); Na (meq $100 \mathrm{~g}^{-1}$ ); Cmic:Corg (microbial quotient, \%); UR (urease activity,

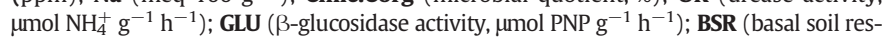
piration, $\mathrm{mg} \mathrm{CO}_{2}-\mathrm{C} \mathrm{kg}^{-1}$ soil per $\mathrm{h}$ ).
BSR and GLU were affected directly by YEAR, and SEVERITY and UR were directly and uniquely related. The YEAR $*$ SEVERITY interaction significantly influenced the GLU values (Table 1 ).

BSR and GLU showed significant differences for the short, the mid and the long terms after fire, with lower values found in B03 than in B15-B21 (Table 2a). The greater SEVERITY, the higher the UR values, which ranged from $0.58 \pm 0.07$ to $0.97 \pm 0.05 \mu \mathrm{mol} \mathrm{NH}_{4}^{+} \mathrm{g}^{-1} \mathrm{~h}^{-1}$ in $\mathrm{UB}$ and $\mathrm{M}-\mathrm{H}$, respectively (Table $2 \mathrm{~b}$ ). GLU showed higher values in the short and mid terms after fire, but lowered according to greater SEVERITY; i.e. no significant differences related to fire severity were observed in B21, which ranged from $0.25 \pm 0.01$ to $0.28 \pm 0.08 \mu \mathrm{mol} \mathrm{PNP} \mathrm{g}{ }^{-1} \mathrm{~h}^{-1}$ in UB and M-H, respectively, where the UB plots had higher GLU values than the burned areas $\left(0.51 \pm 0.01\right.$ and $0.63 \pm 0.10 \mu \mathrm{mol} \mathrm{PNP} \mathrm{g}^{-1} \mathrm{~h}^{-1}$ for B03 and B15, respectively) (Fig. 3).

\subsection{Bivariate correlation coefficients and principal component analysis}

Significant correlations were found among the studied soil variables (Table 3). Several variables correlated with high correlations of the physico-chemical properties $(>0.70)$ : $\mathrm{pH}-$ Corg $(-0.73), \mathrm{pH}-\mathrm{N}$ $(-0.70)$, EC-Mg (0.79), EC-P (0.82), Corg-Ca (0.72), Corg-CEC (0.72), CEC-N (0.81), CEC-Ca (0.79), where Corg-N was the highest (0.94). The biological variables correlated well with one another $(>0.60)$ : GLU-K (0.64), BSR-Cmineral (0.63), Cmic-Cmic:Corg (0.70), CmicCmineral (0.60). The highest correlation was found between Cmic: Corg-Cmineral (0.90).

A principal component analysis (PCA) reduced the variables to a three-component solution (eigenvalues $>1$ ), which was simplified to a two-component solution to obtain greater significance (Fig. 4). The first component (COMP1) accounted for $36.99 \%$, while the second explained 14.08\% (COMP2). The highest explained variability was found in a rotation in which two components accumulated $51.07 \%$ of the variability contained in the original data. The variables included in the COMP1 were $\mathrm{pH}(-0.30)$, Corg, $\mathrm{C}$ and $\mathrm{N}$ ( 0.30 each), and we named the component the "long-term ecosystem response". The variables included in COMP2 were BSR (0.30), Cmic $(-0.39)$, Cmineral $(-0.42)$, and Cmic:Corg ( -0.43$)$, which was named the "short- and mid-term ecosystem response" (Table 4). The long-term responses, represented by the points representing B21, clearly clustered along the COMP1 

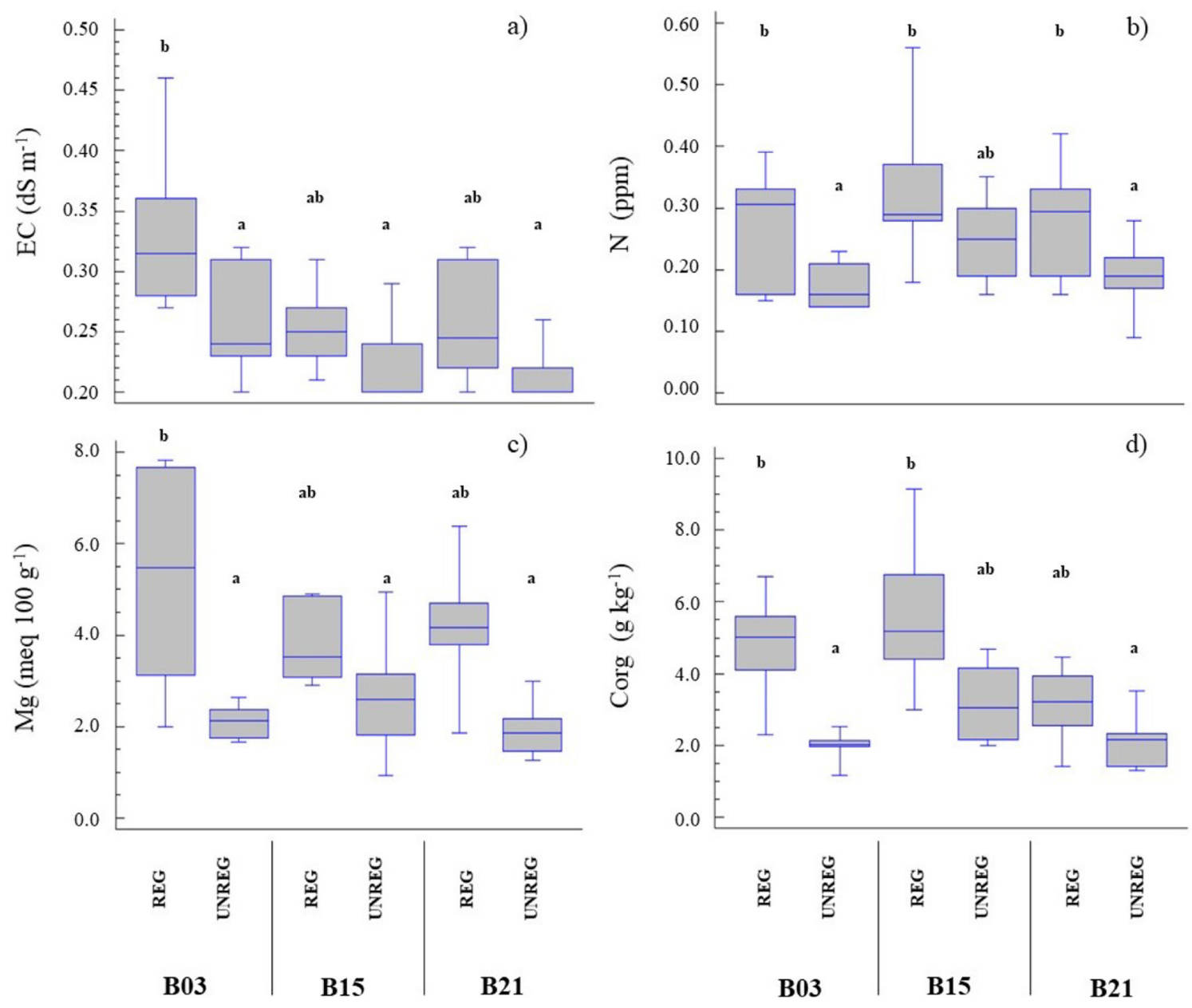

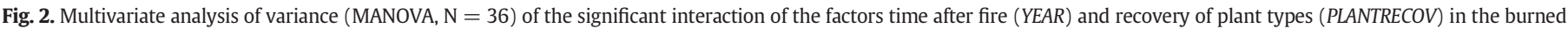

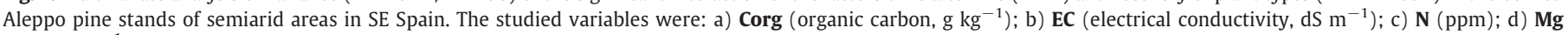

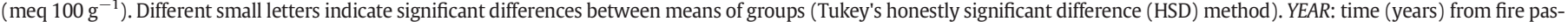

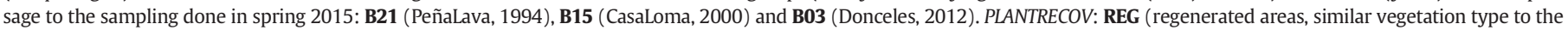
pre-fire conditions) or UNREG (degraded areas or bare soil increased to above $50 \%$ ).

axis, while the overlapping of the points corresponding to the response in the mid and short terms (B03 and B15) clustered to COMP2 (Fig. 4).

\section{Discussion}

We checked that mature Aleppo pine forests showed no significant site-related differences. Thereby the effects of wildfires on the studied variables were explained by the studied factors. As we were comparing similar ecosystems for plant communities and diversity (González-de Vega et al., 2016) and soil characteristics, we ensured that the differences and relationships obtained in the soil indicators were induced by the studied factors. However, we found complex interactions of variables, mainly between Corg-N and Cmic:Corg-Cmineral, in this synchronic approach developed for the burned stands in three different large wildfires with weights that were certainly moderated.

The direct effect of wildfires on soil properties, mainly the combustion degree of soil organic matter, indirectly affected other processes, such as soil aggregation or biological properties (Zavala et al., 2014). We found that most of the changes related to the soil chemical parameters would not imply major effects since scarcely varied or quickly recovered. Some parameters, $\mathrm{pH}, \mathrm{EC}$ and $\mathrm{P}$, increased after fire because of organic matter combustion, related to fire severity and the release of soluble inorganic ions (Certini, 2005). The concentrations of some macronutrients ( $\mathrm{N}, \mathrm{Na}$ and $\mathrm{Mg}$ ) were related to time after fire, but not to fire severity. The changes in soil texture and CEC were attenuated by plant coverage, which is similar to that found in nearby pinewoods (Hedo et al., 2015).

However most of the variables correlated, especially P-EC, N-Corg, $\mathrm{N}-\mathrm{CEC}$, CEC-Corg and Cmic:Corg-Cmineral with high correlation values (>80\%), which explained the complex interrelationships in soil of direct fire damage and indirect effects. The biological parameters were related to time after fire (BSR and GLU) or plant recovery (Cmic:Corg), but also indirectly to changes in chemical parameters, which correlated negatively to $\beta$-glucosidase in the short term ( 3 years after fire) (Granged et al., 2011).

Fire reduced soil ecosystemic services, but only in the short term after fire. However, if fire severity exceeded soil resistance, it could not be recovered during the long-term period (Eivazi and Bayan, 1996). According to our work scale, burn severity effects were attenuated by interactions of natural processes, such as the recovery of combusted Corg due to burned biomass, and those added by new seedlings and resprouts. Besides the time to recover potential soil quality (Zavala et al., 2014), we highlight a good relationship between plant and soil recovery as the interactions in the plant-soil interphase influenced ecosystem resilience, which could depend on soil seed bank composition and the plant community's adaptive strategies (López-Poma and Bautista, 2014; Maia et al., 2012; Pausas et al., 2004). However, the described effects were not significant in the mid and long terms after fire. Indeed soil recovered its pre-fire values during the period from 3 to 15 years after fire. Similar results have been found in 


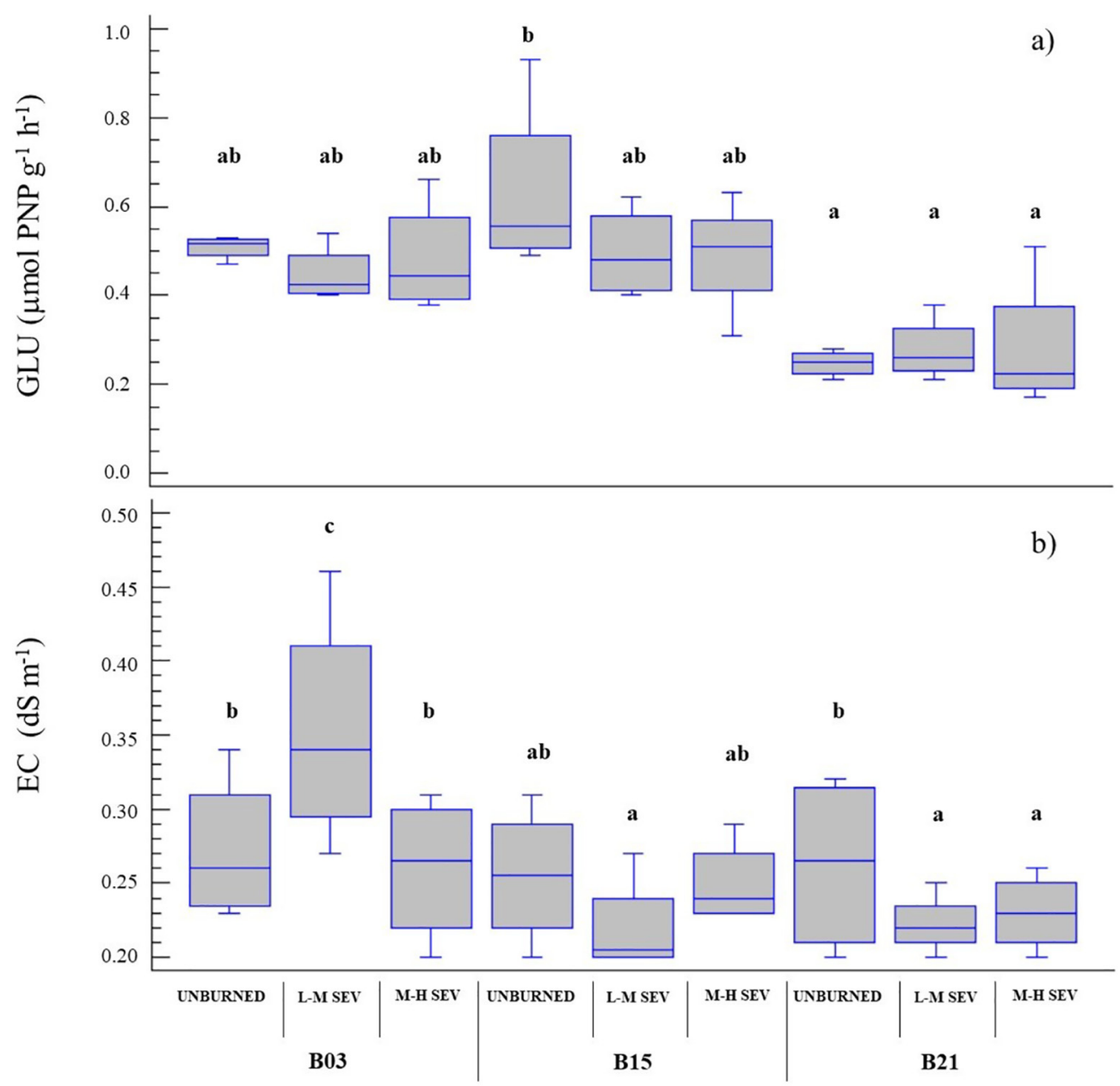

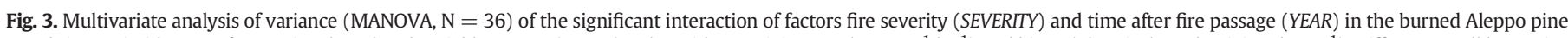

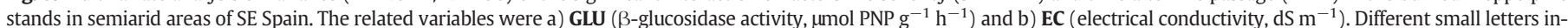

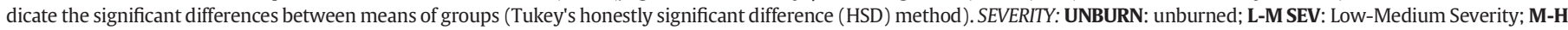
SEV: Medium-High Severity. YEAR: time (years) from fire passage to the sampling in spring 2015: B21 (PeñaLava, 1994), B15 (CasaLoma, 2000$)$ and B03 (Donceles, 2012 ).

pinewoods where biological, physical and chemical soil changes persisted up to 25 months post-fire, which suggests that soil nutrients are not a primary driver of the changes observed in the microbial community composition (Mikita-Barbato et al., 2015). In our study, time after fire also interacted with the plant recovery levels, which were strikingly similar in the mid and long terms (González-de Vega

Table 3

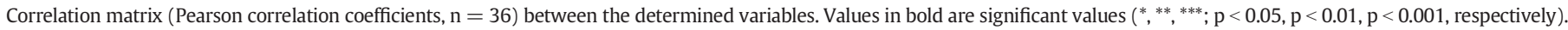
The rows and columns with no significant values are not included.

\begin{tabular}{|c|c|c|c|c|c|c|c|c|c|c|c|c|c|c|c|}
\hline & $\mathrm{pH}$ & $\mathrm{EC}$ & Corg & $\mathrm{N}$ & $C: N$ & $\mathrm{P}$ & $\mathrm{K}$ & $\mathrm{Ca}$ & $\mathrm{Mg}$ & CEC & BSR & Cmic & UR & GLU & Cmic:Corg \\
\hline EC & $-0.45^{*}$ & & & & & & & & & & & & & & \\
\hline Corg & $-0.73^{* *}$ & $0.53^{*}$ & & & & & & & & & & & & & \\
\hline $\mathrm{N}$ & $-0.70^{* *}$ & $0.62^{* *}$ & $0.94^{* * *}$ & & & & & & & & & & & & \\
\hline $\mathrm{C}: \mathrm{N}$ & -0.31 & 0.04 & $0.45^{*}$ & 0.15 & & & & & & & & & & & \\
\hline $\mathrm{P}$ & -0.33 & $0.82^{* *}$ & 0.39* & $0.47^{*}$ & 0.03 & & & & & & & & & & \\
\hline K & $0.48^{*}$ & -0.28 & -0.25 & -0.27 & 0.07 & $-0.34^{*}$ & & & & & & & & & \\
\hline $\mathrm{Na}$ & 0.08 & -0.24 & -0.09 & -0.07 & -0.13 & -0.15 & $0.36^{*}$ & & & & & & & & \\
\hline $\mathrm{Ca}$ & $-0.41 *$ & 0.33 & $0.72^{* *}$ & $0.63^{* *}$ & $0.37^{*}$ & 0.30 & -0.03 & & & & & & & & \\
\hline $\mathrm{Mg}$ & $-0.49^{*}$ & $0.79^{* *}$ & $0.60^{*}$ & $0.64^{*}$ & 0.23 & $0.57^{*}$ & -0.15 & 0.24 & & & & & & & \\
\hline CEC & $-0.74^{* *}$ & $0.46^{*}$ & $0.85^{* *}$ & $0.81^{* *}$ & $0.37^{*}$ & $0.40^{*}$ & -0.27 & $0.79^{* *}$ & $0.52^{*}$ & & & & & & \\
\hline BSR & -0.27 & $0.34^{*}$ & 0.24 & 0.23 & -0.02 & 0.28 & $-0.46^{*}$ & 0.21 & 0.29 & 0.32 & & & & & \\
\hline Cmic & 0.00 & 0.23 & -0.04 & 0.09 & $-0.45^{*}$ & 0.12 & -0.33 & 0.00 & 0.15 & 0.12 & $0.59^{*}$ & & & & \\
\hline GLU & $-0.34^{*}$ & 0.03 & 0.25 & 0.23 & 0.02 & 0.10 & $-0.64^{* *}$ & 0.27 & 0.02 & $0.45^{*}$ & $0.42^{*}$ & 0.25 & $0.37^{*}$ & & \\
\hline PHP & -0.31 & 0.10 & $0.38^{*}$ & $0.38^{*}$ & -0.03 & -0.07 & $-0.34^{*}$ & $0.48^{*}$ & 0.13 & $0.50^{*}$ & 0.31 & $0.39^{*}$ & $0.36^{*}$ & $0.55^{*}$ & \\
\hline $\mathrm{qCO}_{2}$ & -0.29 & 0.14 & $0,35^{*}$ & 0,20 & $\mathbf{0 , 3 8} *$ & 0,14 & $-0,20$ & 0,29 & 0,11 & 0,23 & $0,58^{*}$ & $-0,26$ & $-0,20$ & 0,20 & \\
\hline Cmic:Corg & $0.38^{*}$ & -0.16 & $-0,50^{* *}$ & $-0,40$ & $-0,60^{* *}$ & $-0,16$ & $-0,25$ & $-0,33$ & $-0,31$ & $-0,37^{*}$ & $\mathbf{0 , 3 6}{ }^{*}$ & $0,70^{* *}$ & $-0,07$ & 0,16 & \\
\hline Cmineral & 0.29 & -0.11 & $-0,39^{*}$ & $-0,34^{*}$ & $-0,46^{*}$ & $-0,09$ & $-0,32$ & $-0,25$ & $-0,24$ & $-0,28$ & $0,63^{* *}$ & $0,60^{*}$ & $-0,14$ & 0,28 & $0,90^{* * * *}$ \\
\hline
\end{tabular}

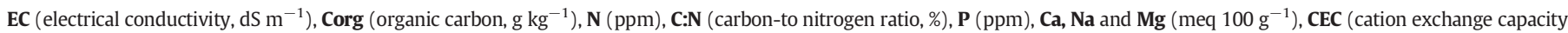

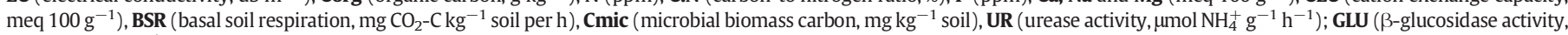

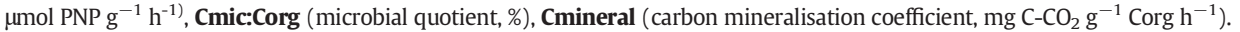




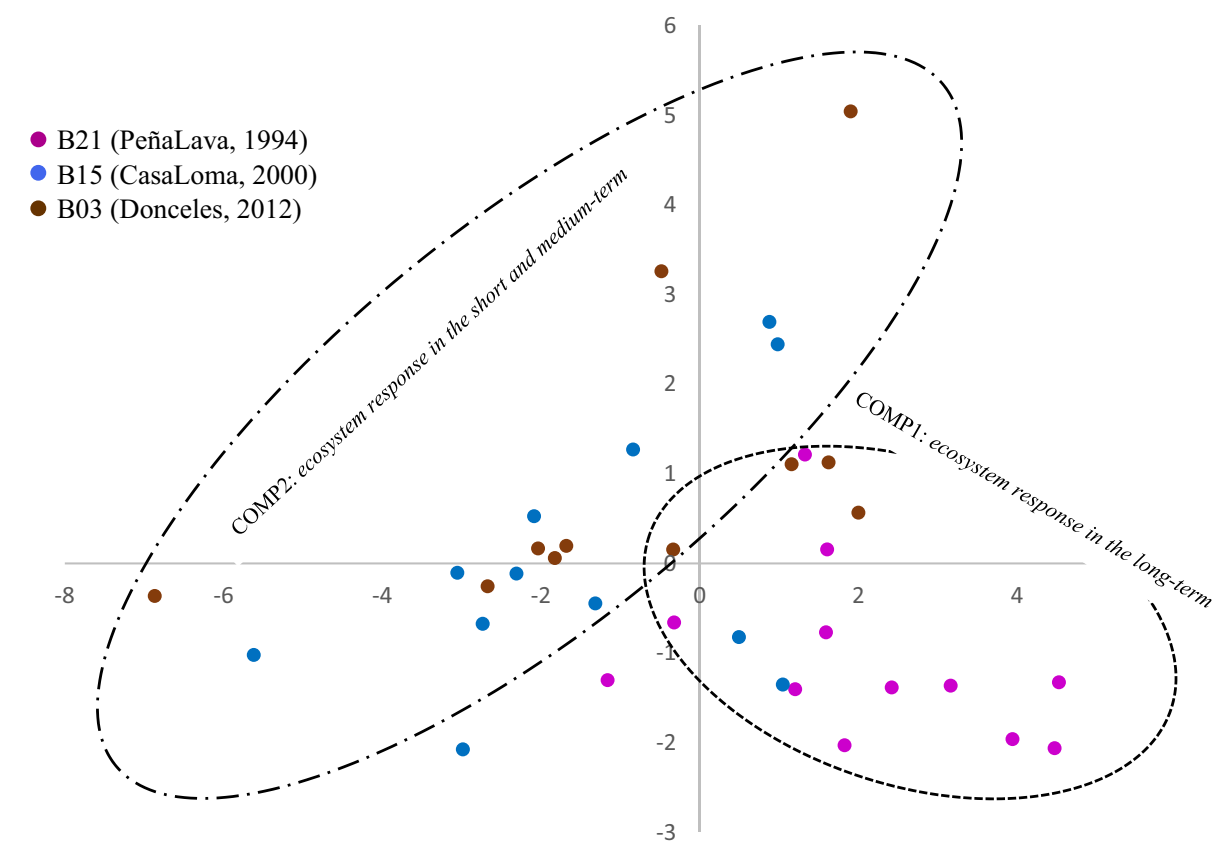

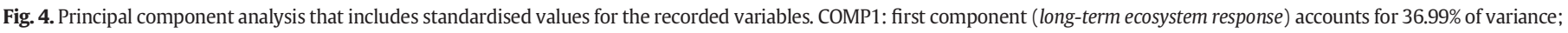

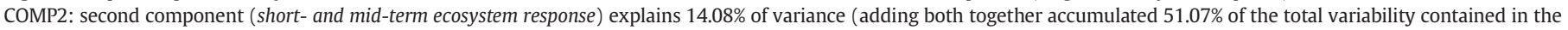
original data).

et al., 2016) as the plant community recovered in time depending on fire severity (Hedo et al., 2014). We related the plant community and soil recovery, explained by post-fire heterotrophic biomass enhancing nitrification to promote plant growth (Hanan et al., 2016). However, the natural vegetation recovery in our synchronic chronosequence differed in the spatial distribution given the multiple ecological interactions and scales of variability. In this way, post-fire succession did not follow a homogeneous pattern on low scales, like that used in this experiment (Morgan et al., 2014). Our findings suggest that fire effect patterns are associated with the spatial scale used to measure the selected soil quality indicators, influenced by microtopography, fire behaviour, post-fire nutrient patterns or water availability, as they promote a complex process in the soil-plant interphase (Rice, 1993).

Fire severity influenced the population of soil microorganisms. DeBano et al. (1998) argued that sensitivity depends on microbial groups because the direct killing of some groups alters reproductive capabilities. In any case, the positive relationship found between vegetation type (including plant diversity, maturity and coverage) and soil microbial biomass recovery reinforces the hypothesis of the positive response of the plant-soil interphase to variations in fire severity and

Table 4

Weights of the variables in the two main components found in the principal component analysis. Bold values are significant and the rows with no significant values are not included. COMP1: first component in the PCA (long-term ecosystem response); COMP2: the second component in the PCA (the short- and mid-term ecosystem response).

\begin{tabular}{lll}
\hline & COMP1 & COMP2 \\
\hline pH & $\mathbf{- 0 . 3 0}$ & -0.04 \\
Corg & $\mathbf{0 . 3 1}$ & 0.13 \\
N & $\mathbf{0 . 3 1}$ & 0.08 \\
BSR & 0.15 & $\mathbf{0 . 3 0}$ \\
Cmic & 0.07 & $\mathbf{- 0 . 3 9}$ \\
Cmic:Corg & -0.11 & $\mathbf{- 0 . 4 3}$ \\
Cmineral & -0.07 & $\mathbf{- 0 . 4 2}$
\end{tabular}

Corg (soil organic carbon, $\mathrm{g} \mathrm{kg}^{-1}$ ); $\mathbf{N}(\mathrm{ppm})$; $\mathbf{B S R}$ (basal soil respiration, $\mathrm{mg} \mathrm{CO}_{2}-\mathrm{C} \mathrm{kg}^{-1}$ soil per day), Cmic (microbial biomass carbon, $\mathrm{mg} \mathrm{kg}^{-1}$ soil); Cmic: Corg (microbial quotient, \%); Cmineral (carbon mineralisation coefficient, $\mathrm{mg} \mathrm{C}-\mathrm{CO}_{2} \mathrm{~g}^{-1} \mathrm{Corg} \mathrm{h}{ }^{-1}$ ). recovery time (Lange et al., 2015). Accordingly, our results supported that approaches for soil resilience, measured as a holistic property (Todman et al., 2016), had to include measurements of soil microorganisms, structure and functional diversity (Caldwell, 2005; PrendergastMiller et al., 2017).

In our study, fire severity influenced soil quality indicators, but also interacted with time after fire and plant recovery, which could be the most important driver of soil microflora changes (Mataix-Solera et al., 2009; Saá et al., 1998). Natural plant recovery increased soluble organic carbon, which allowed populations of microorganisms to rapidly grow, and explained the changes found in basal soil respirations and metabolic quotient (Guerrero et al., 2005). $\beta$-glucosidase and acid phosphatase were not affected by fire severity, but have been previously checked as indicators of fire severity in nearby areas of SE Spain (López-Poma and Bautista, 2014). Urease activity was uniquely related to fire severity and could be considered an indicator of post-fire soil quality in the studied ecosystems. The consequence of the disturbances caused by fire depend on several parameters, such as soil types, vegetation cover, topography, post-fire precipitation, human management, ash type and fire recurrence, which could differently affect and vary the time for soil biology and nutrients to recover (Francos et al., 2018; Pereira et al., 2016; Pereira et al., 2018).

Emergency post-fire actions are usually implemented to recover soil properties, such as organic amendments, straw, mulching, hillslope treatments, road and trail treatments and salvage logging (Vega et al., 2013a). However, no intervention is a useful tool to prevent, mitigate and reduce soil degradation (Pereira et al., 2018). To select a proper tool to mitigate soil degradation, other factors than soil quality should be considered, such as plant recovery (mainly resprouters), drought periods after fire and soil resilience by avoiding, in any case for these stands, salvage logging immediately after fire and including no intervention as a useful tool to reduce soil degradation (López-Poma and Bautista, 2014; Pereira et al., 2018). In fact our findings indicated that fire severity was relevant only in the short term given the high resilience of Mediterranean ecosystems in semiarid areas of SE Spain. The plant-soil interphase presented wide vulnerability to a new wildfire for at least 21 years, irrespectively of the fire severity that could occur. 
Only when fire recurrence was $<21$ years and if the ecosystem continued in the immaturity risk period could a new disturbance reduce ecosystem services by producing ecosystem degradation levels that would make recovery difficult.

\section{Conclusions}

Our work provides insights into how plant functional traits, fire severity and post-fire dynamics modulated the soil biochemical and microbiological response to fire in Mediterranean fire-prone shrublands. During the 15-21 post-fire period, natural regeneration and soil interactions patterns indicated a null influence of fire severity, but the relationship was strong for the short-term period.

Adaptive forest management should include considerations to prevent fire recurrence $<21$ years (high vulnerability of the plant-oil interphase) and to promote reduced fire severity. Restoration management should promote the resilience and resistance of ecosystems including no intervention as a passive tool, to preserve plant diversity, promote resprouters and prevent soil degradation. These measures gain relevance in a changing context, mainly in fire-prone areas with changing fire regimes located in arid and semiarid regions, which are commonly undermanaged and where biological soil stability is more vulnerable. Wildfires can dramatically affect soil properties and nutrient cycling, but the proper restoration of a plant community and post-fire rehabilitation can stabilise and mitigate negative effects. Therefore, adaptive forest management should include tools to reduce fire severity and recurrence, such as prescribed fires and proper rehabilitation after wildfires, and mainly in areas with a high risk of desertification. These tools should also include a monitoring and evaluation framework to quantify the success rate of improvements to resistance, vulnerability and resilience.

\section{Acknowledgments}

We wish to thank the Regional Castilla-La Mancha Government (Junta de Comunidades de Castilla-La Mancha) for its help and field support, Helen Warburton for reviewing the English, and the anonymous reviewers for their valuable comments and suggestions to improve the quality of this paper. This study was supported by a grant for research initiation provided by the Excma. Diputación Albacete (DIPU4AB2015) and by the funds provided by University Castilla-La Mancha to the Forest Ecology Research Group. The authors with to thank the Spanish Institute for Agricultural and Food Research and Technology (INIA) for the funding awarded through National Research Projects GEPRIF (RTA2014-00011-C06).

\section{Appendix A. Supplementary data}

Supplementary data associated with this article can be found in the online version, at doi:https://doi.org/10.1016/j.scitotenv.2018.05.212. These data include the Google map of the most important areas described in this article.

\section{References}

Alfaro-Sánchez, R., Camarero, J.J., López-Serrano, F.R., Sánchez-Salguero, R., Moya, D., de Las Heras, J., 2014. Positive coupling between growth and reproduction in young post-fire Aleppo pines depends on climate and site conditions. Int. J. Wildland Fire 24 (4), 507-517.

Alloza, J.A., García, S., Gimeno, T., Baeza, M.J., Vallejo, V.R., 2014. Guía técnica para la gestión de montes quemados. Ministerio de Agricultura, Alimentación y Medio Ambiente (188 pp).

Bárcenas-Moreno, G., García-Orenes, F., Mataix-Solera, J., Mataix-Beneyto, J., Baath, E., 2011. Soil microbial recolonisation after a fire in a Mediterranean forest. Biol. Fertil. Soils 47 (3), 261-272.

Bárcenas-Moreno, G., García-Orenes, F., Mataix-Solera, J., Mataix-Beneyto, J., 2016. Plant community influence on soil microbial response after a wildfire in sierra Nevada National Park (Spain). Sci. Total Environ. 573, 1265-1274.
Bodí, M.B., Muñoz-Santa, I., Armero, C., Doerr, S.H., Mataix-Solera, J., Cerdà, A., 2013. Spatial and temporal variations of water repellency and probability of its occurrence in calcareous Mediterranean rangeland soils affected by fires. Catena 108, 14-25.

Bond, W.J., Keeley, J.E., 2005. Fire as a global 'herbivore': the ecology and evolution of flammable ecosystems. Trends Ecol. Evol. 20, 387-394.

Bremmer, J.M., Mulvaney, C.S., 1982. Nitrogen total. In: Page, A.L., Miller, R.H., Keeney, D.R (Eds.), Methods of Soil Analysis. Part 2. Chemical and Microbiological Properties. Soil Science Society of America and American Society of Agronomy, Madison, WI, pp. 595-624.

Caldwell, B.A., 2005. Enzyme activities as a component of soil biodiversity: a review. Pedobiologia 49, 637-644.

Capitanio, R., Carcaillet, C., 2008. Post-fire Mediterranean vegetation dynamics and diversity: a discussion of succession models. For. Ecol. Manag. 255 (3-4), 431-439.

Certini, G., 2005. Effects of fire on properties of forest soils: a review. Oecologia 143 $1-10$.

Choromanska, U., Deluca, T.H., 2002. Microbial activity and nitrogen mineralization in forest mineral soils following heating: evaluation of post-fire effects. Soil Biol. Biochem. 34 (2), 263-271.

Dale, V.H., Joyce, L.A., Mcnulty, S., Neilson, R.P., Ayres, M.P., Flannigan, M.D., Hanson, P.J., 2001. Climate change and forest disturbances. Bioscience 51 (9), 723-734.

Debano, L.F., Neary, D.G., Ffolliott, P.F., 1998. Fire's Effects on Ecosystems. John Wiley \& Sons, New York, NY (331 pp).

Diaz-Delgado, R., Lloret, F., Pons, X., 2003. Influence of fire severity on plant regeneration through remote sensing imagery. Int. J. Remote Sens. 24, 1751-1763.

Doblas-Miranda, E., Martínez-Vilalta, J., Lloret, F., Álvarez, A., Ávila, A., Bonet, F.J., Brotons, L., Castro, J., Curiel Yuste, J., Díaz, M., Ferrandis, P., García-Hurtado, E., Iriondo, J.M., Keenan, T.F., Latron, J., Llusià, J., Loepfe, L., Mayol, M., Moré, G., Moya, D., Peñuelas, J., Pons, X., Poyatos, R., Sardans, J., Sus, O., Vallejo, V.R., Vayreda, J., Retana, J., 2015. Reassessing global change research priorities in Mediterranean terrestrial ecosystems: how far have we come and where do we go from here? Glob. Ecol. Biogeogr $24,25-43$.

Doblas-Miranda, E., Alonso, R., Arnan, X., Bermejo, V., Brotons, L., de Las Heras, J., Estiarte, M., Hódar, J.A., Llorens, P., Lloret, F., López-Serrano, F.R., Martínez-Vilalta, J., Moya, D., Peñuelas, J., Pino, J., Rodrigo, A., Roura-Pascual, N., Valladares, F., Vilà, M., Zamora, R. Retana, J., 2017. A review of the combination among global change factors in forests, shrublands and pastures of the Mediterranean region: beyond drought effects. Glob. Planet. Chang. 148, 42-54.

Egler, F.E., 1954. Vegetation science concepts. I. Initial floristic composition-a factor in oldfield vegetation development. Vegetatio 4, 412-418.

Eivazi, F., Bayan, M.R., 1996. Effects of long term prescribed burning on the activity of selected soil enzymes in an oak-hickory forest. Can. J. For. Res. 26, 1799-1804.

Francos, M., Úbeda, X., Pereira, P., Alcañiz, M., 2018. Long-term impact of wildfire on soils exposed to different fire severities. A case study in Cadiretes Massif (NE Iberian Peninsula). Sci. Total Environ. 615, 64-671.

García, C., Hernández, M.T., Costa, F., 1997. Potential use of dehydrogenase activity as an index of microbial activity in degraded soils. Commun. Soil Sci. Plant Anal. 28 $123-134$.

Gee, W.G., Or, D., 2002. Particle-size Analysis. In: Dane, J., Topp, G.C. (Eds.), Methods of Soil Analysis. Book Series: 5. Part 4. Soil Science Society of America, USA, pp. 255-293.

Gómez-Sánchez, E., de Las Heras, J., Lucas-Borja, M., Moya, D., 2017. Assessing fire severity in semi-arid environments: application in Donceles 2012 wildfire (SE Spain). Rev. Teledetección 49, 103-113.

González-De Vega, S., de Las Heras, J., Moya, D., 2016. Resilience of Mediterranean terrestrial ecosystems and fire severity in semiarid areas: responses of Aleppo pine forests in the short, mid and long term. Sci. Total Environ. 573, 1171-1177.

Granged, A.J.P., Zavala, L.M., Jordán, A., Bárcenas-Moreno, G., 2011. Post-fire evolution of soil properties and vegetation cover in a Mediterranean heathland after experimental burning: a 3-year study. Geoderma 164, 85-94.

Guénon, R., Vennetier, M., Dupuy, N., Roussos, S., Pailler, A., Gros, R., 2013. Trends in recovery of Mediterranean soil chemical properties and microbial activities after infrequent and frequent wildfires. Land Degrad. Dev. 24, 115-128.

Guerrero, C., Mataix-Solera, J., Gómez, I., García-Orenes, F., Jordán, M.M., 2005. Microbia recolonization and chemical changes in a soil heated at different temperatures. Int J. Wildland Fire 14, 385-400.

Hanan, E.J., Schimel, J.P., Dowdy, K., D'Antonio, C.M., 2016. Effects of substrate supply, pH, and char on net nitrogen mineralization and nitrification along a wildfire-structured age gradient in chaparral. Soil Biol. Biochem. 95, 87-99.

Hedo, J., Rubio, E., Dadi, T., López-Serrano, F.R., Alfaro-Sánchez, R., Moya, D., De Las Heras J., 2014. Is Remote Sensing a Good Method to Define Forest Fire Resilience? A Particular Case in the Southeastern of the Iberian Peninsula. Imprensa da Universidade de Coimbra.

Hedo, J., Lucas-Borja, M.E., Wic, B., Andrés Abellán, M., De Las Heras, J., 2015. Experimental site and season over-control the effect of Pinus halepensis in microbial properties of soil under semiarid and dry conditions. J. Arid Environ. 116, 44-52.

Hinojosa, M.B., Parra, A., Laudicina, V.L., Moreno, J.M., 2016. Post-fire soil functionality and microbial community structure in a Mediterranean shrubland subjected to experimental drought. Sci. Total Environ. 573, 1178-1189.

Keeley, J.E., 2009. Fire intensity, fire severity and burn severity: a brief review and suggested usage. Int. J. Wildland Fire 18, 116-126

Keeley, J.E., Bond, W.J., Bradstock, R.A., Pausas, J.G., Rundel, P.W., 2012. Fire in Mediterranean Ecosystems: Ecology, Evolution and Management. Cambridge University Press, Cambridge.

Lange, M., Eisenhauer, N., Sierra, C.A., Bessler, H., Engels, C., Griffiths, R.I., MelladoVázquez, P.G., Malik, A.A., Roy, J., Scheu, S., Steinbeiss, S., Thomson, B.C., Trumbore, 
S.E., Gleixner, G., 2015. Plant diversity increases soil microbial activity and soil carbon storage. Nat. Commun. 6, 6707.

López-Poma, R., Bautista, S., 2014. Plant regeneration functional groups modulate the response to fire of soil enzyme activities in a Mediterranean shrubland. Soil Biol. Biochem. 79, 5-13.

Maia, P., Pausas, J.G., Arcenegui, V., Guerrero, C., Pérez-Bejarano, A., Mataix-Solera, J., Varela, M.E.T., Fernandes, I., Pedrosa, E.T., Keizer, J.J., 2012. Wildfire effects on the soil seed bank of a maritime pine stand-the importance of fire severity. Geoderma 191, 80-88.

Mataix-Solera, J., Guerrero, C., García-Orenes, F., Barcenas, G.M., Torres, M.P., 2009. Forest fire effects on soil microbiology. In: Cerdá, A., Robichaud, P.R. (Eds.), Fire Effects on Soil and Restoration Strategies. Science publishers, Endfield, pp. 133-176.

Mikita-Barbato, R.A., Kelly, J.J., Tate III, R.L., 2015. Wildfire effects on the properties and microbial community structure of organic horizon soils in the New Jersey Pinelands. Soil Biol. Biochem. 86, 67-76.

Miller, J.D., Thode, A.E., 2007. Quantifying burn severity in a heterogeneous landscape with a relative version of the delta normalized burn ratio (dNBR). Remote Sens. Environ. 109, 66-80.

Morgan, P., Keane, R.E., Dillon, G.K., Jain, T.B., Hudak, S.T., Karau, E.C., Sikkink, P.G., Holden, Z.A., Strand, E.K., 2014. Challenges of assessing fire and burn severity using field measures, remote sensing and modeling. Int. J. Wildland Fire 23, 1045-1060.

Morugán-Coronado, A., García-Orenes, F., Cerdà, A., 2015. Changes in soil microbial activity and physicochemical properties in agricultural soils in eastern Spain. Span. J. Soil Sci. 5 (3), 201-213.

Moya, D., de Las Heras, J., López-Serrano, F.R., Ferrandis, P., 2015. Post-fire seedling recruitment and morpho-ecophysiological responses to induced drought and salvage logging in Pinus halepensis Mill. stands. Forests 6 (6), 1858-1877.

Nelson, D.W., Sommers, L.E., 1982. Total carbon, organic carbon and organic matter. In: Page, A.L., Miller, R.H., Keeney, D.R. (Eds.), Methods of Soil Analysis. Part 2. Chemical and Microbiological Properties. Soil Science Society of America and American Society of Agronomy, Madison, WI, pp. 539-579.

Olsen, S.R., Sommers, L.E., 1982. Phosphorus. In: Page, A.L., Miller, R.H., Keeney, D.R. (Eds.), Methods of Soil Analysis. Part 2. Chemical and Microbiological Properties. Soil Science Society of America and American Society of Agronomy, Madison, WI, pp. 403-430.

Pausas, J.G., Keeley, J.E., 2014. Abrupt climate-independent fire regime changes. Ecosystems $17,1109-1120$.

Pausas, J.G., Bradstock, R.A., Keith, D.A., Keeley, J.E., Fire Network, G.C.T.E., 2004. Plant functional traits in relation to fila in crown-fire ecosystems. Ecology 85, 1085-1100.

Pereira, P., Cerda, A., Jordan, A., Zavala, L., Mataix-Solera, J., Arcenegui, V., Misiune, I. Keesstra, S., Novara, A., 2016. Short-term vegetation recovery after grassland fire in Lithuania: the effects of fire severity, slope position and aspect. Land Degrad. Dev. 27 (5), 1523-1534.

Pereira, P., Francos, M., Brevik, E.C., Ubeda, X., Bogunovic, I., 2018. Post-fire soil management. Curr. Opin. Environ. Sci. Health 5, 26-32.

Prendergast-Miller, M.T., de Menezes, A.B., MacDonald, L.M., Toscas, P., Bissett, A., Baker G., Farrell, M., Richardson, A.E., Wark, T., Thrall, P.H., 2017. Wildfire impact: natura experiment reveals differential short-term changes in soil microbial communities. Soil Biol. Biochem. 109, 1-13.

Quezel, P., 2000. Taxonomy and biogeography of Mediterranean pines (Pinus halepensis and P. brutia). In: Ne'eman, G., Trabaud, L. (Eds.), Ecology, Biogeography and
Management of Pinus halepensis and P. brutia Forest Ecosystems in the Mediterranean Basin. Backhuys publishers, Leiden, pp. 1-12.

Rice, S.K., 1993. Vegetation establishment in post-fire Adenostoma chaparral in relation to fine-scale pattern in fire intensity and soil nutrients. J. Veg. Sci. 4, 115-124.

Rivas-Martínez, S., 1982. Estage bioclimatiques, secteurs chorologiques et série de vegetation de l'Espagne méditerranéenne. Ecología Mediterr. 8, 275-288.

Roig, A., Romero, M., Lax, A., Fernández, F.G., 1980. Estudio comparativo de métodos de determinación de capacidad de cambio catiónica en suelos calizos. An. Edafología Agrobiología 39, 2021-2032.

Saá, A., Trasar-Cepeda, M.C., Carballas, T., 1998. Soil P status and phosphomonoesterase activity of recently burnt and unburnt soil following laboratory incubation. Soil Biol. Biochem. 30 (3), 419-428.

San-Miguel-Ayanz, J., Rodrigues, M., Santos De Oliveira, S., Kemper Pacheco, C., Moreira, F., Duguy, B., Camia, A., 2012. Land cover change and fire regime in the European Mediterranean region. In: Moreira, F., Arianoustsou, M., Corona, P., de las Heras, J. (Eds.), Post-Fire Management and Restoration of Southern European Forestsmanaging Forest Ecosystems. 24, pp. 21-43.

Soil Survey Staff, 2014. Keys to Soil Taxonomy. 12th ed. USDA-Natural Resources Conservation Service, Washington, DC.

Tabatabai, M.A., 1994. Enzymes. In: Weaver, R.W., Angle, J.S., Bottomley, P.S. (Eds.), Methods of Soil Analysis. Part 2. Soil Science Society of America and American Society of Agronomy, Madison, WI, pp. 755-833.

Tessler, N., Sapir, Y., Wittenberg, L., Greenbaum, N., 2016. Recovery of Mediterranean vegetation after recurrent forest fires: insight from the 2010 forest fire on Mount Carmel, Israel. Land Degrad. Dev. 27, 1424-1431.

Todman, L.C., Fraser, F.C., Corstanje, R., Deeks, L.K., Harris, J.A., Pawlett, M., Ritz, K., Whitmore, A.P., 2016. Defining and quantifying the resilience of responses to disturbance: a conceptual and modelling approach from soil science. Sci. Rep. 6, 28426.

Vallejo, V.R. Arianoutsou, M., Moreira, F, 2012. Fire ecology and post-fire restoration approaches in southern European forest types. In: Moreira, F., Arianoustsou, M., Corona, P., de las Heras, J. (Eds.), Post-Fire Management and Restoration of Southern European Forests-managing Forest Ecosystems. 24, pp. 93-119.

Vance, E.D., Brookes, P.C., Jenkinson, D.S., 1987. An extraction method for measuring soil microbial biomass C. Soil Biol. Biochem. 19, 703-707.

Vega, J.A., Fontúrbel, T., Fernández, C., Díaz-Raviña, M., Carballas, T., Martín, A., GonzálezPrieto, S., Merino, A., Benito, E., 2013a. Acciones urgentes contra la erosión en áreas forestales quemadas. Guía para su planificación en Galicia. Centro de Investigación Forestal de Lourizán (Consellería do Medio Rural e do Mar, Xunta de Galícia). Instituto de Investigaciones Agrobiológicas de Galicia del CSIC (IIAG-CSIC), Universidad de Santiago de Compostela, Universidad de Vigo, FUEGORED, Santiago de Compostela (139 pp).

Vega, J.A., Fontúrbel, T., Merino, A., Fernández, C., Ferreiro, A., Jiménez, E., 2013b. Testing the ability of visual indicators of soil burn severity to reflect changes in soil chemical and microbial properties in pine forests and shrubland. Plant Soil 369, 73-91.

Zavala, L.M., de Celis, R., Jordán, A., 2014. How wildfires affect soil properties. A brief review. Cuad. Investig. Geográfica 40 (2), 311-331. 